\title{
Metabolism of $\alpha$ - Linolenic Acid (ALA) in Meat Animals
}

\author{
Pilar Teresa Garcia \\ Area Bioquímica y Nutrición \\ Instituto Tecnología Alimentos, ITA \\ Centro de Investigación en Agroindustria, CIA \\ Instituto Nacional de Tecnnología Agropecuaria, INTA \\ INTA Castelar, CC77(B1708WAB) Moron, Pcia Buenos Aires \\ Argentina
}

\section{Introduction}

A key function of ALA (C18:3n-3) is as substrate for the synthesis of longer-chain omega 3 fatty acid found in fish EPA (C20:5 n-3) and DHA (C22:6 n-3) which play an important role in the regulation of inflammatory immune reactions and blood pressure, brain development, cognitive function, etc. (Sirot et al., 2008).

The American Heart Association (AHA) recommends to increase the consumption of n-3 fatty acids and to reach a low omega 6/omega 3 ratio for reach a healthy status (Russo, 2009). Fat is an important component of the human diet, but current levels of intake are considered too high and the overall fatty acid composition imbalanced. There is an excessive intake of saturated fatty acids (SFA) relative to polyunsaturated fatty acids (PUFA), expressed usually as the P/S ratio, and the consumption of $n-6$ PUFA is too high relative to n-3 PUFA. The ratio of n- $6 / n-3$ PUFA is a risk factor in cancers and coronary heart disease, especially the formation of blood clots leading to a heart attack. More recently, nutritionists have focused on the type of PUFA and the balance in the diet between n-3 PUFA formed from C18:3 n-3 and the n-6 PUFA from C18:2 n-6 (Willians, 2001)

ALA and LNA (C18:2 n-6) serve as the precursor molecules from which the rest of fatty acids belonging to the n-3 and n- 6 fatty acid family can be synthesized through a series of elongation and desaturation reactions. All the reactions are catalyzed by an enzymatic system consisting in fatty acyl-CoA synthetases $\Delta-6$ and $\Delta-5$ desaturases and respective elongases. These two fatty acid families not only share these enzymes, but they also compete for the same enzymes (Brenner, 1989).

There are two basic metabolic fates for ALA. First it is subjected to $\beta$-oxidation and extensive carbon recycling. Second, it is converted into longer fatty acids via elongation and desaturation. The predominant fate of ALA is catabolism (Demar et al. 2005) and carbon recycling to acetate (Cunnane et al., 1997, 2003). In rodents, only 16\% of an ALA dose is found in rat tissues, mainly adipose, and 6\% was elongated /desaturated (Kaduce et al., 2008). Increasing the ALA content of the maternal diet of sucking rats led to increased of ALA, EPA and DPA (C22:5 n-3) in the whole body, skin epididymal fat pads and but there was no effect on the DHA content of these tissues nor on the brain or muscles (Bordoni et 
al., 1996). For studies on ALA metabolism, the main focus is to establish if it is converted in sufficient quantities to maintain adequate tissue levels of DHA. Although less importance has been given to the EPA and DPH accumulation.

The conversion of ALA from vegetal oils in long-chain fatty acids EPA (C20:5 n-3), DPA (C22:5 n-3) and DHA (C22:6 n-3) is a hot point in this moment because many studies considere that its conversion is not important. There is little doubt regarding the essential nature of ALA, yet the capacity of dietary ALA to maintain adequate issue levels of longchain fatty acids remains quite controversial (Barcelo-Coblijn \& Murphy, 2009).

The metabolization of ALA to long-chain seems to be affected for several factors as amounts of other fatty acids in the diet as LA, sex, animal species, etc. Several reviews concerning the ALA metabolism to EPA, DPA and DHA have appeared recently (Brenna, 2002; Burdge \& Calder. 2005)

EPA and DHA present different effects on several functions of leukocytes, insulin secreting cells, and endothelial cells. These differences are associated with their effects on membrane physicochemical, intracellular signalling pathways and gene expression (Gorjao et al., 2009). The marked differences between the effects of EPA and DHA indicate that it not possible to generalize the effects of omega 3 fatty acids on cell function. Substantial improvement in the therapeutic usage of n-3 fatty acids will be possible with the discovery of the different mechanisms of actions of DHA and EPA.

Meat, fish, fish oils and eggs are the only significant sources of long-chain n-3 PUFA for man. Although meat has lower concentrations of these FA compared to oily fish, it is a very significant source for many people, since fish consumption is low. The low PUFA concentration and the high concentrations of saturated FA in ruminant tissues result from the biohydrogenation of dietary PUFA in the rumen. (Harfoot \&Hazlewood, 1988). Ruminal micro-organisms in vitro did not hydrogenate EPA and DHA to any significant extent (Ashes et al., 1992). Several studies have been published covering studies describing manipulation of the fatty acid composition of animal meat but paying less attention to long chain PUFA.

Soybean oil is one of the few plant sources providing ample amounts of both essential fatty acids C 18:2 n- 6 and C18:3 n-3. The fatty acid content of soy foods is often unrecognized by health professionals, perhaps because there is so much focus on soy proteins. The major fatty acids in soy oil are the essential fatty acid linoleic (C18:2 n-6) $(54 \%)$, oleic acid (C22\%), palmitic acid (C16:0) and the essential omega 3 fatty acid alfa- linolenic (C18:3 n-3) (8\%). Soybeans are used in cattle, poultry and pigs diets and could be a more important source of ALA for animal nutrition and also increase ALA and its fatty acids metabolites in meats. Canola oil is the other important source in commercial oils that contain the precursor alfa linolenic acid (ALA). The main sources of ALA are presented in Table 1.

Genomics, specifically marker assisted plant breeding combined with recombinant DNA technology, provided powerful means for modifying the composition of oilseeds to improve their nutritional value and provide the functional properties required for various food oils (Owen \& Sing, 2005).

Transgenic canola oil was obtained that contains $>23 \%$ of SDA (C18:4 n-3). In a clinical study (James et al., 2003) observed that SDA was superior to ALA as a precursor by a factor of 3.6 in producing EPA, DHA and DPA (C22:5 n-3).

Modern plant husbandry, either through selective breeding or genetic modifications, affords the opportunity to alter the fatty acid profile of plants. The result was the development of soybean plants, traditionally rich in PUFA, which are high in MUFA, and rapeseed plants traditionally rich in MUFA, which are high in PUFA (Hazebrock, 2000). 


\begin{tabular}{|c|c|c|}
\hline Common name & Scientific name & A LA/100g material \\
\hline Flaxseed & Linum usitatissimum & $22.8 \mathrm{a}$ \\
\hline Flaxseed oil & & $53.3 \mathrm{a}$ \\
\hline Perilla & Perilla frutescens & 58.0 \\
\hline Chia seed & Salvia hispanica & $17.6 \mathrm{a}$ \\
\hline Camelin oil & Camelina Sativa & $38.0 \mathrm{c}$ \\
\hline Canola oil & Brassica campestris & $9.1 \mathrm{a}$ \\
\hline Soybeen oil & Glycine max & $6.8 \mathrm{a}$ \\
\hline Soybeen green raw & & 0.4 \\
\hline Walnuts & Juglans regia & $9.1 \mathrm{a}$ \\
\hline Cloudberry & Rubus chamaemorus & $1.2 \mathrm{~b}$ \\
\hline Blueberry & Vaccine corymbosum & $0.8 \mathrm{~b}$ \\
\hline Cowberry & Vaccinium vitis-idaea & $0.2 \mathrm{~b}$ \\
\hline
\end{tabular}

a) Agricultural Research Service USA 2009

b) Bere E. , 2007

c) Karvonen et al., 2002

Table 1. Main natural sources of ALA

\section{Conversion of ALA into long-chain n-3 PUFA in meat animals}

The potential use of livestock products as vehicles to deliver n-3 fatty acids has been the subject of intensive research (Moghadasian, 2008).

The lipid composition of animal body tissues largely depends on the feeding background of the meat producing non-ruminant animals. There has been an increased interest in the substitution of animal fat sources with vegetable oils in animal nutrition.

Vegetable oils have been attributed with reducing the level of saturation in animal fat tissue due to their unsaturated fatty acid concentration when compared with animal fat.

Since some meats naturally have a P/S ratio of around 0.1 , meat has been implicated in causing the imbalanced fatty acid intake of today's consumers. Thus the recommended ratio should be increased to above 0.4 . In addition, some vegetable oils are rich in n-3 PUFA, mostly C18:3 n-3.

Increasing the $\mathrm{n}-3$ content in animal meats can be achieved by including fish oil or fish meal in the diet, rich in EPA and DHA or vegetable oils rich in ALA. Diet rich in ALA results in an increased level of ALA, EPA, and DPA in the meat, while in most cases no effect on DHA level was observed.

Several reviews have been published covering studies describing manipulation of animal meat but paying less attention to long chain PUFA. All data should be presented as $\mathrm{g} / 100 \mathrm{~g}$ of total fatty acids to obtain a better comparison of results originated from studies with large differences in fat content. Fatty acid of neutral fraction was characterized by a high proportion of SFA and MUFA, whereas the PL fraction showed a high proportion of PUFA (Raes, De Smet \& Demeyer, 2004).

Fish oil and other marine raw materials are limited, expensive and the quality varies.

EPA and DHA, and to a lesser extent DPA, are mainly found in marine products, and fish oil additions to pig diets have been evaluated in several experiments with different inclusion levels. Overland et al. (1996) fed pigs with 1\% and 3\% dietary fish and found a dose-dependent increase in long-chain n-3 PUFA in fat and muscle. 
From a general stand point, fish oil supplementation seems to be the most effective way to increase tissue deposition on DHA, whereas the dietary inclusion of ingredients, flaxseed and flaxseed oil, containing its precursor, ALA, results only in a small increase in DHA, probably due to the limited conversion of DPA to DHA (Riley et al 2000, Raes \& De Smet, 2004, Portolesi, Powell \& Gibson, 2007; Pawlosky et al., 2003).

Microalgae, the original source of DHA in the marine food chain (Abril et al, 2003) have been included in animal feeds to improve the DHA level of foods of animal origin.

In Tables 2, 3, 4 and 5 are present the effect of different feeding in the proportions of ALA, EPA, DPA and DHA in pork, poultry, beef and lamb meats.

\begin{tabular}{|l|l|l|l|l|l|}
\hline & ALA & EPA & DPA & DHA & Reference \\
\hline Grass silage only (GS) & 1.88 & 1.00 & 1.52 & 0.24 & Faucitano et al. (2008) \\
\hline $\begin{array}{l}\text { Growing: GS+4\% Soybean } \\
\text { Finish: GS+ 4\% barley }\end{array}$ & 0.83 & 0.39 & 0.85 & 0.13 & Faucitano et al. (2008) \\
\hline $\begin{array}{l}\text { Growing: GS+8\% soybean } \\
\text { Finish: GS+ 8\% barley }\end{array}$ & 0.72 & 0.31 & 0.63 & 0.09 & Faucitano et al. (2008) \\
\hline & & & & & \\
\hline C German Holstein bulls & 0.34 & 0.14 & 0.36 & 0.09 & Nuernberg et al. (2005) \\
\hline Grass German Holstein bulls & 1.67 & 0.58 & 0.80 & 0.15 & Nuernberg et al. (2005 \\
\hline C German Simental bulls & 0.46 & 0.08 & 0.29 & 0.05 & Nuernberg et al. (2005 \\
\hline Grass German simental bulls & 2.22 & 0.94 & 1.32 & 0.16 & Nuernberg et al. (2005 \\
\hline & & & & & \\
\hline Pasture only & 1.30 & 0.52 & 0.71 & 0.43 & Garcia et al. (2008) \\
\hline Pasture+0.7\% corn grain & 0.89 & 0.31 & 0.51 & 0.18 & Garcia et al. (2008) \\
\hline Pasture+1.0\% corn grain & 0.74 & 0.26 & 0.49 & 0.14 & Garcia et al. (2008) \\
\hline Concentrate & 0.28 & 0.12 & 0.30 & 0.16 & Garcia et al. (2008) \\
\hline & & & & & \\
\hline Grass + 4 kg C & 0.71 & 0.20 & ND & & Woods et al. 2011 \\
\hline 8 kg concentrate+1 kg hay & 0.72 & 0.12 & ND & & Woods et al. 2011 \\
\hline 6 kg grass+5 kg C & 0.87 & 0.27 & ND & & Woods et al. 2011 \\
\hline 12 kg grass+2.5 kg C & 1.01 & 0.24 & ND & & Woods et al. 2011 \\
\hline 22 kg grass & 1.13 & 0.23 & ND & & Woods et al. 2011 \\
\hline & & & & & \\
\hline Feedlot & 0.48 & 0.47 & 0.91 & 0.11 & Alfaia et al. 2009 \\
\hline Pasture+ 4 month C & 0.84 & 0.77 & 1.04 & 0.12 & Alfaia et al. 2009 \\
\hline Pasture+ 2 month C & 1.96 & 1.28 & 1.48 & 0.14 & Alfaia et al. 2009 \\
\hline Pasture only & 5.53 & 2.13 & 2.56 & 0.20 & Alfaia et al. 2009 \\
\hline & & & & & \\
\hline
\end{tabular}

C concentrate

Table 2. Effect of dietary source of ALA on the long-chain n-3 PUFA of the beef Longissimus muscle (\% of total fatty acids) 


\begin{tabular}{|l|l|l|l|l|l|}
\hline & ALA & EPA & DPA & DHA & Reference \\
\hline Pasture LD & 2.64 & 1.07 & 0.91 & 0.41 & Garcia et al. (2008) \\
\hline Pasture Leg muscles & 2.89 & 1.37 & 1.23 & 0.41 & Garcia et al. (2008) \\
\hline $\begin{array}{l}\text { Extruded linseed-high.oleic } \\
\text { rapessed }\end{array}$ & 2.20 & 0.58 & 0.75 & 0.17 & Berthelot et al. (2010) \\
\hline $\begin{array}{l}\text { Extruded linseed normal } \\
\text { rapeseed }\end{array}$ & 2.38 & 0.60 & 0.79 & 0.20 & Berthelot et al. (2010) \\
\hline Extruded linseed-soybean & 2.58 & 0.75 & 0.97 & 0.22 & Berthelot et al. (2010) \\
\hline & & & & & \\
\hline Grazing T. subterraneum & 1.97 & 0.48 & 0.92 & 0.64 & Chiofalo et al. (2010) \\
\hline Grazing L.Multiflorum & 1.52 & 0.47 & 0,90 & 0.64 & Chiofalo et al. (2010) \\
\hline & & & & & \\
\hline Control (C)High concentrate diet & 4.18 & 0.07 & 0.06 & 0.31 & Radunz et al. (2009) \\
\hline Soy bean + linseed oil (2:1) & 4.90 & 0.04 & 0,02 & 0.32 & Radunz et al. (2009) \\
\hline & & & & & \\
\hline Grass hay & 2.27 & 1.23 & 0.77 & 0.38 & Demirel et al. (2006) \\
\hline Concentrate & 0.72 & 0.60 & 0.31 & 0.17 & Demirel et al. (2006) \\
\hline & & & & & \\
\hline Soy oil replaced with 0\% & 0.93 & 0.19 & 0.46 & 0.14 & Jeronimo et al (2009) \\
\hline Soy oil replaced with 33.3\% & 1.57 & 0.29 & 0.54 & 0.15 & Jeronimo et al (2009) \\
\hline Soy oil replaced with 66.6\% & 2.62 & 0.51 & 0.62 & 0.19 & Jeronimo et al (2009) \\
\hline Soy oil replaced with 100\% & 3.05 & 0.50 & 0.54 & 0.20 & Jeronimo et al (2009) \\
\hline
\end{tabular}

Table 3. Effect of dietary source of ALA on the long-chain n-3 PUFA of lamb Longissimus muscle (\% of total fatty acids)

\subsection{Conversion of ALA in humans}

If humans receive an ALA- enriched source there are a generally increase in ALA, EPA and DPA in plasma, in red blood cells and in mononuclear cells (Goyens et al., 2006). More controversial and less consistent are found in regards of the conversion and accumulation of DHA from dietary ALA.

Several reviews concerning the issue of ALA metabolism to EPA, DPA and DHA have appeared recently (Brenna,2002;Burdge et al.2005). Recently Brenna et al. 2009 concluded that there is a little doubt regarding the essential nature of ALA, yet the capacity of dietary ALA to maintain adequate tissue levels of long-chain n-3 fatty acids remains quite controversial.

\subsection{Conversion of ALA in pigs}

Different factors determine the fatty acid composition in pig's carcasses (Wiseman et al., 2000). In non-ruminants, the fatty acid pattern of dietary lipids is reflected in the fatty acid composition of tissues. Dietary strategies used to customize FA composition of pig fat have been proven to be very effective because dietary fatty acids can be incorporated into pig fat with little modifications (Bee, Jacot, Guex \& Biolley, 2008). 


\begin{tabular}{|c|c|c|c|c|c|}
\hline & ALA & EPA & DPA & DHA & Reference \\
\hline $6 \%$ crushed linseed 20 days & 2.77 & 0.68 & 0.90 & 0.44 & Kouba et al. (2003) \\
\hline $6 \%$ crushed linseed 60 days & 3.00 & 0.77 & 0.82 & 0.21 & Kouba et al. (2003) \\
\hline $6 \%$ crushed linseed 100 days & 2.19 & 0.44 & 0.63 & 0.11 & Kouba et al. (2003) \\
\hline Control LD & 0.49 & 0.13 & 0.34 & 0.15 & Huang et al. (2008) \\
\hline Linseed $(10 \%) 30$ days LD & 2.46 & 0.46 & 0.56 & 0.15 & Huang et al. (2008) \\
\hline Linseed (10\%) 60 days LD & 3.32 & 0.61 & 0.65 & 0.16 & Huang et al. (2008) \\
\hline No fat & 0.47 & ND & 0.12 & 0.06 & Duran et al. (2010) \\
\hline Tallow (T) & 0.93 & 0.03 & 0.21 & 0.11 & Duran et al. (2010 \\
\hline High oleic sunflowe oil (SFHO) & 0.72 & ND & 0.14 & 0.11 & Duran et al. (2010 \\
\hline Sunflower oil (SFO9 & 0.70 & ND & 0.17 & 0.15 & Duran et al. (2010 \\
\hline Linseed oil (LO) & 14.18 & 0.27 & 0.43 & 0.10 & Duran et al. (2010 \\
\hline $\mathrm{T}(55 \%)+\mathrm{SFHO}(35 \%)+\mathrm{LO}(15 \%)$ & 5.42 & 0.13 & 0.36 & 0.14 & Duran et al. (2010 \\
\hline Fish oil $(40 \%)+\mathrm{LO}(60 \%)$ & 8.86 & 0.93 & 1.02 & 3.11 & Duran et al. (2010 \\
\hline Palm kernel oil LD & 0.63 & ND & 0.48 & 0.34 & Teye et al. (2010) \\
\hline Palm oil $\quad$ LD & 0.57 & ND & 0.54 & 0.36 & Teye et al. (2010 \\
\hline Soybean oil & 0.87 & ND & 0.47 & 0.27 & Teye et al. (2010 \\
\hline $\begin{array}{l}\text { Corn }+W C R+0 \% \text { Soybean oil } \\
\text { LD }\end{array}$ & 0.33 & 0.06 & 0.23 & 0.16 & Wang et al. (2011) \\
\hline $\begin{array}{l}\text { Corn+WCR+8\% Soybean oil } \\
\text { LD }\end{array}$ & 0.52 & 0.08 & 0.29 & 0.19 & Wang et al. (2011) \\
\hline $\begin{array}{l}\text { Corn+WCR+12\% Soybean oil } \\
\text { LD }\end{array}$ & 0.68 & 0.11 & 0.27 & 0.21 & Wang et al. (2011) \\
\hline $\begin{array}{l}\text { Corn+WCR+16\% Soybean oil } \\
\text { LD }\end{array}$ & 0.72 & 0.08 & 0.29 & 0.15 & Wang et al. (2011) \\
\hline Basal+ 3 \% Rapessed oil LD & 3.03 & & 0.15 & 0.11 & Tikk et al. (2007) \\
\hline Basal $+3 \%$ Palm oil $\quad$ LD & 1.17 & & 0.09 & 0.08 & Tikk et al. (2007) \\
\hline Basal $\quad$ LD & 0.55 & 0.22 & 0.47 & 0.14 & Haak et al. (2008) \\
\hline Linseed crushed 3\% LD & 1.24 & 0.54 & 0.75 & 0.18 & Haak et al. (2008) \\
\hline Fish oil $10 \% \quad$ LD & 0.47 & 1.37 & 0.82 & 1.02 & Haak et al. (2008) \\
\hline
\end{tabular}

Table 4. Effect of dietary source of ALA on the Long-chain n-3 PUFA of pork muscles (\% of total fatty acids)

Different studies agree in that saturated fatty acids are deposited to a higher extent than unsaturated fatty acids (Leyton et al., 1987) and that the degree of deposition of fatty acids increases as fatty acid length increases. In relation to unsaturated fatty acids it seems that as unsaturation increases, deposition decreases (DeLany et al., 2000). However, differences in the relationships between intake and deposition exist, and these relate to whether the specific FA can be synthesized in vivo (Enser et al., 2000). Duran-Monge et al. (2010) found that deposition rates where between 65 and $73 \%$ for diets rich in LA and between 63 and $64 \%$ for diets rich in ALA. 


\begin{tabular}{|c|c|c|c|c|c|}
\hline & ALA & EPA & DPA & DHA & Reference \\
\hline \multicolumn{6}{|l|}{ Breast } \\
\hline Control $+3 \%$ rapessed oil & 2.33 & 0.07 & 0.57 & 0.32 & Kitessa \& Young (2009) \\
\hline Control $+3 \%$ Echium oil & 6.50 & 0.24 & 1.09 & 0.37 & Kitessa \& Young (2009) \\
\hline \multicolumn{6}{|l|}{ Thigh } \\
\hline Control $+3 \%$ rapessed oil & 2.84 & 0.03 & 0.12 & 0.03 & Kitessa \& Young (2009) \\
\hline Control + 3\% Echium oil & 6.40 & 0.17 & 0.33 & 0.08 & Kitessa \& Young (2009) \\
\hline Control Breast & 1.76 & 0.10 & Traces & 0.01 & Rondelli et al. (2007) \\
\hline Control+5\% chia seeds & 6.73 & 0.65 & Traces & 0.86 & Rondelli et al. (2007) \\
\hline Control $+10 \%$ chia seeds & 9.26 & 0.68 & Traces & 1.01 & Rondelli et al. (2007) \\
\hline Control Tigh & 1.44 & $\operatorname{Tr}$ & $\operatorname{Tr}$ & $\operatorname{Tr}$ & Rondelli et al. (2007) \\
\hline Control+5\% chia seeds & 6.56 & 0.29 & $\operatorname{Tr}$ & $\operatorname{Tr}$ & Rondelli et al. (2007) \\
\hline Control $+10 \%$ chia seeds & 9.56 & 0.21 & $\operatorname{Tr}$ & $\operatorname{Tr}$ & Rondelli et al. (2007) \\
\hline \multicolumn{6}{|l|}{ Breast } \\
\hline $\begin{array}{l}\text { 15\% Sunflower high oleic } \\
\text { (SFHO) }\end{array}$ & 2.03 & 0.13 & 0.82 & 0.79 & Lozupone at al. (2009) \\
\hline $15 \%$ Flax seed + SFHO & 7.91 & 0.79 & 1.93 & 1.46 & Lozupone at al. (2009) \\
\hline $15 \%$ Canola + SFHO & 2.79 & 0.16 & 0.92 & 0.86 & Lozupone at al. (2009) \\
\hline $15 \%$ Chia+SFHO & 10.82 & 0.61 & 1.51 & 1.02 & Lozupone at al. (2009) \\
\hline $15 \%$ Chia expeller +SFHO & 8.73 & 0.42 & 1.19 & 0.95 & Lozupone at al. (2009) \\
\hline \multicolumn{6}{|l|}{ Breast } \\
\hline Concentrate +Soybean & 1.71 & 0.13 & 0.79 & 0.75 & Azcona et al. (2008) \\
\hline $\begin{array}{l}\text { Concentrate + soybean } \\
\text { pasture }\end{array}$ & 1.61 & 0.27 & 0.65 & 0.87 & Azcona et al. (2008) \\
\hline Linseed+SFHO+pasture & 4.32 & 0.39 & 1.22 & 1.45 & Azcona et al. (2008) \\
\hline Basal & 1.29 & 0.07 & 0.38 & 0.14 & Crespo et al. (2002) \\
\hline Tallow & 1.26 & 0.05 & 0.51 & 0.25 & Crespo et al. (2002) \\
\hline Olive oil & 1.14 & 0.05 & 0.32 & 0.17 & Crespo et al. (2002) \\
\hline Sunflower oil & 0.98 & nd & 0.03 & 0.18 & Crespo et al. (2002) \\
\hline Linseed oil & 35.28 & 1.01 & 0.91 & 0.35 & Crespo et al. (2002) \\
\hline Control (Corn-soybean) & 3.19 & 0.11 & 0.57 & 0.47 & Azcona et al. (2008) \\
\hline Flaxseed $(15 \%)$ & 10.03 & 0.55 & 119 & 0.85 & Azcona et al. (2008) \\
\hline Rapeseed (15\%) & 3.69 & 0.16 & 0.70 & 0.60 & Azcona et al. (2008) \\
\hline Chia seed (15\%) & 11.73 & 0.92 & 1.23 & 0.72 & Azcona et al. (2008) \\
\hline Chia meal (15\%) & 8.82 & 0.32 & 1.16 & 0.89 & Azcona et al. (2008) \\
\hline
\end{tabular}

Table 5. Effect of dietary source of ALA on the Long-chain n-3 PUFA of poultry meat (\% of total fatty acids) 
The deposition rate for long-chain PUFA was 33.6\%, 47, 9\% and 48.9\% for ARA (C20:4 n-6), EPA an DHA respectively. When no EPA and DHA were added to the diet, high linolenic acid content $s$ in the diet only can increase EPA contents in the whole animal but not DHA. Mathematical relationships between the dietary concentration of PUFA and the fatty acid composition of back fat and intramuscular fat of swine have been established (Nguyen et al., 2003).

Poumes-Ballihaut et al. (2001) have shown that the tissue concentrations of the long-chain n-3 PUFA, particularly DHA, are lower in an ALA-based diet than one in which the performed long-chain n-3 PUFA are presented. Barcelo-Coblijn et al. (2005) found in guinea pigs, both the brain and retina DHA levels were greater when a diet containing $1 \%$ of ALA and $1.8 \%$ of DHA was fed relative to one with only $7.1 \%$ ALA. When guinea pigs were fed a high level of ALA, many tissues had very substantial increases in ALA, EPA and DHA but comparatively little increase in DHA.

Pork normally has a high C18:2 content, producing a high $\mathrm{P} / \mathrm{S}$ ratio, but an unfavourable n$6 / n-3$ ratio. A major aim of the feeding strategy was to improve the $n-6 / n-3$ ratio, whilst maintaining a beneficially high P/S ratio.The n-3 PUFA level can be increased in pork by feeding fat sources as linseed, which contains abundance of C18:3 n-3, C18:3 n-3 might elongate in pig tissues to produce long chain n-3 PUFA (Wood \& Enser 1997). Conversely, a higher proportion of long chain n-6 PUFA derived from linoleic acid results in a proinflammatory status. The ratio of $n-6 / n-3$ PUFA is a risk factor in cancers and coronary heart disease, especially the formation of blood clots leading to a heart attack (Enser, 2001). More recently, nutritionists have focused on the type of PUFA and the balance in the diet between n-3 PUFA formed from C18:3 n-3 and the n-6 PUFA from C18:2 n-6 (Willians 2001) According to Canadians standards, enrichments of n-3 PUFA, can be obtained in pork products when relatively low levels of back fat from pigs fed flaxseed are included. with pig diets supplemented with vegetable oils such as soybean oil, sunflower oil, and corn oil, contain a high percentage of PUFA and should lead to healthy products for consumers.

Flax is a rich oilseed source of ALA and feeding flax to pigs has been used to increase levels of n-3 PUFA in pork, as reviewed by Nuijens et al. (2003). The effect of feeding flaxseed on tissue deposition on n-3 PUFA in pigs has been found to be quite variable. Feeding extracted flaxseed oil likely provides the most digestible form of ALA, but would be relatively expensive for inclusion in swine diets. Huang et al. (2008) found 9,72\% n-3 PUFA in back fat fatty acids when feeding $10 \%$ flax to pigs for close to 13 weeks.

Several authors have reported a lack of effect of flax diets on tissue levels of DHA and only a few studies have reported increased levels of DHA after feeding a relative low level (2-2.5\%) of dietary flax (Corino, Musella \& Mourot, 2008; Enser et al.,2000). The lack of effect on DHA may be explained by competition for $\Delta 6$ desaturase activity between ALA and the precursor for DHA (i.e. 24:5 n-3), when the dietary concentration of ALA is high (Cameron et al., 2000).The addition of a 50:50 mix of extruded flax/peas to pig diets provided a highly available source of ALA yielding n-3 fatty acid enrichments in back fat comparable to reports when feeding supplemental flax seed oil (Juarez et al., 2010). Kouba et al. (2003) studied the FA composition of longissimus muscle from pigs fed a $6 \%$ crushed linseed diet for 20, 60, or 100 days. The ALA proportions were 2.77, 3.00 and 2,19\% respectively, the EPA $0.68,0.77$ and 0.44 respectively, the DPA $0.90,0.82$ and 0.63 respectively and the DPA 0.44 , 0.21 and $0.11 \%$ respectively. The reason of the absence of effect of linseed-supplemented diets on the proportion of the quantity of DHA in pig's tissues is not clear. It is either 
directly due to the low capacity of the pig to synthesize DHA from EPA, or it is due to a rapid utilization of DHA in pig tissues (Kouba \& Mourt, 2011)

The supplementation of pigs fed with whole crop rice with soy bean- oil at levels of $0,8,12$ or $16 \%$ affected the fatty acid composition of back fat and Longissimus muscle. The concentration of SFA and MUFA in back fat and in Longissimus dorsi muscle decreased significantly with the inclusion of soybean oil in the diet $(\mathrm{p}<0.05)$. The $n-3$ and $n-6$ PUFA were significantly higher in back fat and in Longissimus dorsi muscle of pigs fed diet with soybean oil. The ratios $\mathrm{P} / \mathrm{S}$ were significantly higher and lower in $n-6 / n-3$ in both tissues of pigs fed with soybean oil (Wang et al. 2010). Feeding 3\% of soybean oil to seventy -to crossbreed barrows increased the contents of C18:3 and C18:2 in the neutral lipids and phospholipids in both Longissimus and biceps brachii muscles (Ping et al., 2008).

Male and female pigs were fed diets containing palm kernel oil to fish oil in ratios given as \% inclusion 4.1:0.0, 3.9:0.3, 3.6:0.5, and 3.4:0.7.The levels of EPA, DPA and DHA in M. Longissimus increased in a dose-dependent manner when dietary fish oil increased up to $0.7 \%$. The high levels of DPA compared to a markedly lower percentage of EPA than seen in the diet, suggests a strong activity of EPA elongation. The decrease in the ratio between DPA: EPA with increased inclusion of fish oil further suggests a tendency of saturation of this activity (Hallenstvedt et al., 2010).

In pigs the duration and time of feeding a specific fat source on the muscle FA is dependent on the FA considered. For the deposition of ALA and its conversion to long chain metabolites in muscle after the supply of linseed, only the last phase before slaughter was determinant. When fish oil was used, the greatest EPA and DHA proportions were found in case of a continuous supply throughout the fattening period, and levels of DHA but not EPA were lower when fish oil was fed during the first fattening phase followed by linseed feeding before slaughter (Haak, et al., (2008).

\subsection{Conversion in poultry}

There are opposite deposition patterns between broilers fed fish products and those fed flaxseed and suggests that n-3 fatty acid tissue deposition is source dependent. Fish products are a source of EPA and DHA. whereas crop such as flaxseed provide ALA. Long chain n-3 were either not detected or were detected in very low concentrations in white and dark poultry meats tissues.

Several authors have shown that poultry meat can also be enriched with EPA an DHA by supplementing their diets with marine-based n-3 PUFA sources (Rymer \& Givens, 2005).

The incorporation of dehydrated leguminous- based forage in the diet for broiler chicks results in more favourable polyunsaturated fatty acid/ saturated fatty acids and n-6/n-3 nutritional ratios for animals slaughtered at early stages of grow (Ponte et al., 2008).

Addition of 0.5 and $10 \%$ of chia seed to poultry diets increased in broiler breast lipids the ALA proportions (1.76; 6.73 and $9.26 \%$ respectively), the EPA proportions $(0.10,0.65$, and $0.68 \%$ respectively) and DHA proportions (0.0, 0.86 and $1.01 \%$ respectively (Rondelli et al.,2007)

Broilers fed rapeseed, flaxseed, chia seed and chia meal increase the ALA, long-chain n-3 and total PUFA n-3, contents of white and dark meats. Chia seed gave the highest total PUFA n-3 increasing, yielding 157 and 200\%increases for dark and white meat, respectively (Ayerza et al., 2002; Azcona et al., 2008).

Birds fed Echium oil-supplemented rations had more than double of ALA, SDA, EPA and DPA in tissues than those fed similar rations supplemented with rapeseed oil. Echium oil 
was more effective than rapeseed oil in changing the EPA levels in chicken meat, but the two vegetable oil sources were similar in that they both had no impact on the amount of DHA (Kitessa \& Young, 2009).

\subsection{Conversion in cattle}

Meat from pasture- finished beef has greater amounts of n-3 PUFA compared to concentrate-based diets (French et al., 2000; 2003; Garcia et al., 2008). Similar results were observed by Lorenz et al. (2002) in pasture finished bulls compared to concentrate fed. The types of forage, crop variety, cutting, season, year, etc, affects the fatty acid composition of forage crops for grazing forage beef production (Preston, 2005; Garcia et al., 2007)

The forage-based diets increases ALA in LD muscle as compared with feeding concentrates, agreeing with previous studies with beef cattle comparing alfalfa silage (Mandell et al.,1998) or pasture (French et al., 2000, 2003).

The most common method of enhancing the CLA (cis-9, trans-11 C18:2 isomer) and TVA (trans-11 C18:1) content of ruminant meat and dairy products is to provide the animal with additional dietary unsaturated fatty acids, usually from plants oils such as soybean oil (SBO), for use as substrates for ruminal biohydrogenation (Mir et al., 2003). Steers fed a corn-based diet supplemented with SBO may enhance TVA without impacting CLA, while reducing the MUFA content of lean beef (Ludden et al., 2009).

Bulls grazing on pasture and finished on a diet containing linseed accumulated two or three fold higher concentrations of total n-3 PUFA in their muscles compared to those fed concentrate. The increased concentrations of EPA, DPA and DHA in muscle of animals fed on grass suggests that the high availability of ALA in the diet has resulted in an enhanced synthesis of these n-3 long- chain PUFA (Nuernberg et al., 2005)

Supplementation to Friesian bull calves with a high forage fattening diet with soybean oil or extruded full fat soybeans, at a level of $33 \mathrm{~g}$ added oil per $\mathrm{kg}$ of diet, increases de level of ALA in intramuscular lipids (Aharaoni et al. , 2005).

Concentrates enriched with linseed oil-enriched concentrates results in a favourable n-6/n-3 PUFA ratio. The fatty acid proportion of polar lipids of fat from Longissimus dorsi presented similar proportions of ALA and EPA but less DPA and DHA compared with beef heifers offered pasture only (Noci et al., 2007).

\subsection{Conversion in lamb and sheep}

All n-3 polyunsaturated fatty acids were higher in muscle from lambs fed dried grass- based diet than from lambs fed concentrate-based diets (Demirel, 2006)

Meat from Patagonian lamb raised on natural grasses showed high concentrations of ALA and long-chain fatty acids, EPA, DPA and DHA compared with lipids from other lamb production systems (Garcia et al., 2008).

The feeding regime, herbage or concentrate affected the total n-3 PUFA in Longissimus dorsi muscle of lambs. The herbage regime presented more ALA and EPA but no significant changes in DHA (Vasta et al. 2010).

Berthelot \& Schmidely (2010) used sixty male lambs in two trials to study the efficiency of transfer and elongation of ALA in muscle and caudal adipose tissue. In experimental 1 diet lambs were fed a control diet or extruded linseed diet either with wheat or corn and in experiment 2 lambs were fed with normal rapessed or hig-oleic rapessed, or soybean. In experiment 1 linseed increased ALA proportion and total n-3 PUFA in muscle and adipose tissue. In experiment 2 increasing LA intake increased LA proportion in muscle and adipose tissue but did not modify ALA proportion. They concluded that in agreement with 
published results, feeding extruded linseed increased the proportion of ALA and long-chain n-3 PUFA in the muscle and adipose tissue of intensively-reared lambs fed high starch concentrates. The type of cereal grains was not a major factor of transfer of ALA in carcasses. Increasing LA intake in lambs fed linseed did not affect ALA transfer or elongation and desaturation of long- chain n-3 PUFA in the muscle.

Several strategies have been tested to improve the nutritional value of meat of intensivelyreared lambs, kept indoors and fed high- concentrate diets rich in LA and poor in ALA. Incorporating linseed rich in lipid and ALA in the diet has been advocated by several research (Wachira et al., 2002; Bas et al., 2007) because it induced a high ALA in tissue content and an increase in long-chain PUFA n-3.

The effect of grazing on Trifolium subterraneum and lolium mltiflorum on lamb meat was studied (Chiofalo et al., 2010). The grazed forage species has influenced the fatty acid composition of lamb meat. The grazing on T. subterraneum as monoculture and associated with L. multiflorum in the proportion $\mathrm{T} / \mathrm{L}=66 / 33$ has increased the linolenic acid of L.dorsi muscle.

Supplementation of linseed and soybean oils as a source of PUFA en lambs finishing diets had only modest effects on fatty acid composition on muscle and adipose tissues (Radunz et al., 2009). Similar studies have come to the same conclusion based on effects of feeding unsaturated oil supplementation in high-concentrate diets (Beaulieu et al. ,2002; Engle et al., 2000; Rizzi et al., 2001; Santos-Silva et al., 2003).

The dietary replacement of sunflower oil with linseed oil increases significantly the n-3 PUFA in lamb meat. However, the synthesis of EPA and DHA from dietary C18:3 n-3 seems to be limited, and thus the EPA and DHA enriched lamb meat contributes only in a small amount to the recommended daily intake for humans diet (Jeronimo et al. (2009).

Lambs initially fed with concentrate showed a lower proportion of most of n-3 PUFA than lambs initially fed with lucern in intramuscular fat from Longissimus muscles (Bessa et al., 2008).

Peng et al. (2010) investigated the effects of supplemental oilseeds in the diet (sunflower seed, saflower seed, rapeseed and linseed), on fatty acid composition in different ewes tissues. Beneficial fatty acid content of tissue can be increased by oilseed supplementation, but the magnitude of increase varies according to tissue.

The dietary replacement of sunflower oil with linseed oil increased significantly the n-3 PUFA in lamb meats, with the highest value of n-3 long-chain PUFA achieved with $78 \%$ of sunflower oil with linseed oil replacement. However, the synthesis of EPA and DHA from dietary ALA seems to be limited, and thus the EPA and DHA enriched lamb meat contributes only in a small amount to the recommended daily intake for human diet (Jeronimo et al., 2009).

\section{New sources of long chain PUFA n-3}

It is know that global fish stocks are in danger, so, fish production may decrease in the future. In addition of this, some fishes, especially marine fishes like salmon, sardine, tuna, anchovy, mackerel or hake, are sometimes contaminated with heavy metals as copper or mercury, and organic pollutants as PCBs or dioxins, which have a toxic effect for human health (Domingo et al., 2007). Worm \& Barbier (2006) predicted that sea food resources would face total collapse mid this century.

For that reasons, several alternative sources for omega-3 PUFA have been proposed, as marine microalgaes, algaes or transgenic plants (Lichenstein et al., 2006). 
Marine microalgae, provide the food base that supports the entire animal population in open seas. Cardoso et al., (2007) have reviewed the most recent research on microalgae production of high-value compound having relevance in food science, pharmacology or human health, as PUFA. Marine microalgae are one of the primary producers of long-chain PUFA, and these are capable of converting LNA and ALA to ARA, EPA and DHA, by a series of aerobic desaturations and elongations.

Both LNA and ALA are found in many crop plants such as canola, linseed and soybean and provide a good stating point for transgenic conversion to long-chain PUFA. The transgenic aerobic long-chain PUFA production begins with either a $\Delta 6$-desaturation or a $\Delta 9$-elongation as the first commited steps of two separate pathways that lead to long -chain PUFA. These enzymes can often act on ALA and LNA equally well, resulting in parallel pathways, which yield both omega-3 PUFA and less desirable omega-6 PUFA product including ARA. ARA will only be converted to EPA, and thus DHA, by a $\Delta 17$-desaturation (Wu et al. 2005).

Petrie et al. (2010) have identified and characterised a probable acyl-CoA $\Delta 6$-desaturase with strong omega-3 preference from the marine microalga M. Pusilla. They have used this enzyme in a highly productive pathway in $N$. benthamiana that culminated with the accumulation of $26 \%$ EPA in TAG and have confirmed strong omega 3 preference in transgenic Arabidopsis.

Plants have the capacity to serve as a sustainable source of omega -3 fish oils. In order to investigate the impact of different genes on accumulation of n-3 long chain n-3 PUFA, plants were transformed with a number of recombinant binary plasmids, expressing a range of different genes from a variety of organism under control of seed-specific promoters.

During the last 10 years, genes encoding the primary enzymes involved in biostnthesis of these fatty acids have been succeefully isolated from a range of VLC-PUFA-synthesising organisms with a number of these being heterologously expressed, syngle or in combination, in oil-seed crops (Sayanova et al., 2004; Napier, 2007) Depending of the combination of genes, Ruiz et al., 2010 could identify in Arabidopsis plants lines with high EPA and/or DHA content, and with/ without the accumulation of intermediates. They showed the practical feasibility of large-scale production of these important n-3 PUFA.

Although the biosynthesis of ARA, EPA and to some extent to DHA has been demostrated using different approaches in transgenic plants, the resu

ltant fatty acid composition and levels are not equivalent to that found in fish oil. In most current examples such transgenic plants also contain high levels of n-6 and n-3 metabolic intermediaries (Venegas-Calderon, Sayanova \& Napier, 2010). Fish oils are almost free of omega- 6 fatty acids such as GLA and DHGLA.

Some early results in enriching plant with n-3 PUFA through transgenesis have been reported in Arabidopsis, soybean and rapeseed (Robert et al., 2005; Sato et al., 2004; Ursin, 2003). The profile and relative profile concentrations of fatty acids in corn and soybeen seed from transgenic and isogenic crops was reported by Jimenez et al., 2009.

\section{Conclusions}

The conversion of ALA from vegetal oils in long-chain fatty acids EPA (C20:5 n-3), DPA (C22:5 n-3) and DHA (C22:6 n-3) as a results of many studies with both ruminants and nonruminants is not important, resulting in only a small increase in the deposition of EPA and DPA. The capacity of dietary ALA to maintain adequate issue levels of DHA in meat lipids 
seems to be very low. The nutritional importance of increased ALA concentration is not clear since ALA is not as bioactive as longer chain n-3 PUFA such as EPA, DPA and DHA.

\section{References}

Abril, R., Garret, J., Zeller, S.G., Sander, W.J.\& Mast, R.W. ( 2003). Safety assesment of DHArich microalgae from Schizochytrium sp: Part V. Target animal safety/toxicity in growing swine. Regul.Toxicol. Pharmacol, 7:73-82.

Aharoni, Y, Orlow, A., Brosh, A., Granit, R.\& Kanner, J. (2005). Effects of soybean supplementation of high forage fattening diet on fatty acid profiles in lipid depots of fattening bull calves, and their levels of blood vitamin E. Animal Feed Science and Technology, 119:191-202.

Alfaia, C.P.M., Alves, S.P., Martins, S.I.V., Costa, A.S.H., Fontes, C.M.G.A.,Lemos, J.P.C., Bessa, R.J.B. \& Prates, J.A.M. (2009). Effect of the feeding system on intramuscular fatty acids and conjugated linoleic acid isomers of beef cattle, with emphasis on their nutritional value and discriminatory ability. Food Chemistry, 114:939-946.

Ashes, J. L., Siebert, B.D., Gulati, S.K., Cuthbertson, A.Z. \& Scott, T.W. (1992). Incorporation of n-3 fatty acids of fish oil into tissue and serum lipids of ruminants. Lipids, 27:629631.

Ayerza, R., Coates, W. \& Lauria, M. (2002). Chia seed (Salvia hispanica 1.) as an w-3 fatty acid source for broilers: Influence on fatty acid composition, cholesterol and fat content of white and dark meats, growth performance, and sensory characteristics. Poultry Science, 81: $826-837$.

Azcona, J.O., Garcia, P.T., Cossu, M.E., Iglesias, B.F., Picallo, N.A., Perez, C., Gallinger, C.I., Shang,M.J. \& Canet, Z.E. (2008). Meat quality of Agentinean Camperos chicken enhanced in omega 3 and omega 9 fatty acids. Meat Science, 79:437-443.

Azcona, J.O., Schang, M., Garcia, P.T., , C., Gallinger, C.I., Ayerza, R. \& Coates, W., (2008) Omega -3 enriched broiler meat: The influence of dietary a-linolenic- $\omega-3$ sources on growth, performance and meat fatty acid composition. Canadian Journal of Animal Science, 88:257-269.

Barcelo-Coblijn, G.\& Murphy, E.J. (2009). Alpha-linolenic acid and its conversion to longer chain n-3acids: benefits for human health and a role in maintaining tissue n-3 fatty acid levels. Progress in Lipid Research, 48:355-374.

Bas, P., Berthelot, V., Pottier, E.\& Normand, J.,(2007) Effect of linseed on fatty acid composition of muscles and adipose tissues of lamb with emphasis on trans fatty acids. Meat Science, 77:678-688.

Bauchart, D., Gladine, C., Gruffat, D.,Leloutre, L., \& Durand, D. (2005) Effects of diets supplementd with oil seeds and vitamin E on specific fatty acids of Rectus abdominis muscle in Charolais fattening bulls. In J.F. Hocquette \& S.Gigli (Eds.). Indicators of milk and beef quality 112:431-436 EAAP Publ., Wageningen Academic Publishers.

Beaulieu, A.D., Drackley, J. K. \& Merchen, N.R. (2002) Concentrations of conjugated linoleic acid (cis-9, trans-11-octadecadienoic acid) are not increased in tissue lipids of cattle 
fed a high concentrate diet supplement with soybean oil. Journal Animal Science, 80: 847-861.

Bee, G., Jacot, S., Guex, G.\& Biolley, C. (2008). Effects of two supplementation levels of linseed combined with CLA or tallow on meat quality trits and fatty acid profile of adipose and different muscle tissues in slaughter pigs. Animal, 2:800-801.

Bere, E. (2007). Wild berries: a good source of omega 3. Eur.Journal Clinical Nutrition, 61:431433.

Berthelot, V., Bas, P.\& Schmidely, P. (2010). Utilization of extruded linseed to modify fatty acid composition of intensively-reared lamb meat: Effect of associated cereals (wheat vs. corn) and linoleic acid content of th diet. Meat Science, 84:114-124.

Bessa, R.J.B., Lourenco, M., Portugal, P.V.\& Santos-Silva, J. (2008). Effects of previous diet and duration of soybean oil supplementation on ligh lamb carcass composition, meat quality and fatty acid composition. Meat Science, 80:1100-1105.

Bordoni, A, Lopez Jimenez, J.A.,Spano, C., Biagi, P., Horrobin, D.F.\& Hrelia, S. (1996). Metabolism of linoleic and alpha- linolenic in cultured cardiomyocytes: effect of different n-6 y n-3 fatty acid supplementation.Mol. Cell. Biochem, 157:217-222.

Brenna, J.T., Salem Jr., N., Sinclair, A.J.\& Cunnana, S.C., (2009). Alfa-linolenic acid supplementation and conversion to n-3 long-chain polyunsaturated fatty acids in humans. Prostaglandins, Leukotrienes and Essential Fatty Acids, 80:85-91.

Brenna, J.T. (2002). Efficiency of conversion of a-linolenic to long chain n-3 fatty acids in man. Curr.Opin. Clin.Nutr.Metab.Care, 5:127-132.

Brenner, R.R. (1989). Factors influencing fatty acid chain elongation and desaturation. In A.J. Vergroesen \& M. Crawford (Eds.) The role of fat in humannutrition. London: Academic press.

Burdge, G.C.\& Calder, P.C. (2005). Conversion of a-linolenic acid to longer-chain polyunsaturated fatty acids in human adults. Reprod. Nutr. Dev, 45:581-597.

Cameron, N.D., Wood, J.D., Enser, M.,Wihittington, F.M., Penman J.C.\& Robinson, A.M. (2000). Sensitivity of pig genotypes to short-term manipulation of plasma fatty acids by feeding linseed. Meat Science, 56:379-386.

Cardoso, K.H.M., Guaratini, T., Barros, M.T., Falcao, V.R., Tonon, A.P., Lopez, A.P. et al. (2007). Metabolites from algae with economical impact . Comparative Biochemistry and Physiology, Part C, 146:60-78.

Chiofalo, B., Simonella, S., Di Grigoli, A., Liotta, L.,Frenda, A.S., Lo Presti, V., Bonanno, A. \& Chiofalo, V.(2010). Chemical and acidic compostion of longissimus dorsi of Comisana lambs fed with trifolium subterraneum and Lolium multiflorum. Small Ruminant Research, 88:89-96.

Corino, C., Musella, M.\& Mourot, J. (2008). Influence of extruded linseed on growth , carcass composition, and meat quality of slaughtered pigs at one hundred ten and one hundred sixty $\mathrm{kg}$ of liveweight. Journal Animal Science, 86:1850-1860.

Crespo, N.\& Esteve-Garcia,E. (2002). Dietary polyunsaturated fatty acids decreasefta deposition in separable fat depot but no in the remainder carcass. Poultry Science, 81:512-518.

Cunnane, S.C: \& Anderson, M.J.,(1997). The mayority of dietary linoleato in growing rats is beta-oxidized or stored in visceral fat. Journal of Nutrition, 127:146-152. 
Cunane, S.C.(2003). Problems with essential fatty acids:time for a new paradigm? Progress Lipid Research, 42:544-568.

DeLany, J.P., Windhauser, M.M., Champagne, C.M.\& Bray, G..A (2000). Differential oxidation of individual dietary fatty acids in humans. American Journal Clinical Nutrition, 72:905-911.

Demar, J.C., Ma, K., Chang, I.,Bell, J.M. \& Rapoport, S.I. ( 2005). Alpha linolenic acid does not contribute appreciably to docosahexaenoic acid within brain phospholipids of adult rats fed a diet enriched in docosahexaenoic acid. Journal Neurology, 94:10631076.

Demirel, G., Ozpinar, H., Nazli, B. \& Keser, O. (2006). Fatty acid of lamb meat from to breeds fed different forage: concentrate ratio. Meat Science, 72:229-235.

Domingo, J.L.,Bocio, A., Falco, G. \& Llobet, J.M. (2007).Benefits and risks of fish consumption I. A quantitative analysis of the intake of omega -3 fatty acids and chemical contaminants. Toxicology, 230:219-226.

Duran-Montge,P., Realini,C.E., Barroeta,A.C., Lizardo, R.G.\& Esteve-Garcia, E. (2010). De novo fatty acid synthesis and balance of fatty acids of pigs fed different fat sources. Livestock Science, 132: 157-164.

Engle,T.E., Spears, J.W., Fellner, V. \& Odle, J. (2000). Effects of dietary soybean oil and dietary copper on ruminal and tissue lipid metabolism in finishing steers. Journal Animal Science, 78:2713-2721.

Enser, M., Richardson, R. I., Wood, J.D.,Gill, B.P.\& Sheard, P.R. (2000).Feeding linseed to increase the n-3 PUFA of pork: Fatty acid compositionof muscle, adipose tissue, liver and sausages. Meat Science, 55: 201-212.

Faucitano,l., Chouinard, P.Y., Fortin, J.J., Mandell, I.B., Lafreniere, C.\& Girard, C.L., Berthiaume, R. (2008). Comparison of alternative beef production systems based on forrage finishing or grain-forage diets with or without growth promotans: 2. Meat quality, fatty acid composition, and overall palatability. Journal Animal Science, 86:1678-1689.

French, P., Stanton, C., Lawless, F., O`Riordan, E.G., Monahan, F.J., Caffrey, P.J.\& Moloney, A.P. (2000). Fatty acid composition, including conjugated linoleic acid, of intramuscular fat from steers offered grazed grass, grass silage or concentrate based diets. Journal Animal Science, 78.2849-2855.

French, P., O'Riordan, E. G.,Monahan, F. J., Caffrey, P.J. \& Moloney, A.P. (2003). Fatty acid composition of intramuscular triacylglycerols of fed autumn grass and concentrates. Livestock Production Science, 81:307-317.

García, P. T., Pordomingo, A., Perez, C. A., Rios, M.D.\& Casal, J.J. (2007). Influence of cutting and season on the fatty acid composition of forage crops for grazing forage beef production. Proceedings 53nd International Congress Meat Science \& Technology. 97-98.

Garcia, P.T., Pensel, N.A, Sancho, A.M., Latimori, N.J., Kloster, A. M. , Amigone, M.A.\& Casal, J.J. (2008). Beef lipids in relation to animal breed and nutrition in Argentina. Meat Science, 79:500-508. 
Garcia, P.T:, Casal, J:J:, Fianuchi, S., Magaldi, J.J., Rodriguez, F.J.\& Nancucheo, J.A. (2008). Conjugated linolenic acid (CLA) and poliunsaturated fatty acids in muscle lipids of lamb from the Patagonian area of Argentina. Meat Science, 79:541-548.

Gorjao, R., Acevedo-Martins,A.K.,Gomez Rodrigues, H., Abdulkader, F., Arcisio-Miranda, M., Procopio, J.\& Curi, R. (2009). Comparative effects of DHA and EPA on cell function. Pharmacologia ETherapeutics, 122: 56-64.

Goyens, P.LL.,Spilker, M.E., Zock, P.L., Katan, M.B.\& Mensink, R.P. (2006). Conversion of alinolenic acid in humans is influenced by the absolute amounts of a-linolenic acid and linoleic acid in the diet and not by their ratio. American Journal Clinical Nutrition, 84:44-53.

Haak, L., De Smet, S., Fremaut, D., Van Walleghem, K.\& Raes, K. (2008). Fatty acid profile and oxidative stability of pork as influenced by duration and time of dietary linseed or fish oil supplementation. Journal Animal Science, 86:1418-1425.

Hallenstvedt , E., Kjos, N.P., Rehnberg, A. C., Overland, M.\&Thomassen, M. (2010). Fish oil in feeds for entire male and female pigs: changes in muscle fatty acid composition and stability of sensory quality. Meat Science, 85:182-190.

Harfoot, C.G. \& Hazelwood, G.P. (1988). Lipid metabolism in the rumen. In The Rumen Microbial Ecosystem, $2^{\text {nd }}$ ed. P.N. Hobson, ed. Elservier Science Publishing Co., Inc., New York, NY.

Huang , F.R., Zhan, Z.P., Luo, J.\& Peng, J. (2008). Duration of dietary linseed feeding affects the intramuscular fat, muscle mass and fatty acid compositionin pig muscle. Livestock Science, 118:132-139.

James, M.J., Ursin, V.M.\& Cleland, L.G. (2003). Metabolism of stearidonic acid in human subbjects: comparison with the metabolism of other n-3 fatty acids. American Journal of Clinical Nutrition, 77:1140-1145.

Jeronimo,E., Alves, S.P., Prates, J.A.M., Santos-Silva, J.\& Bessa, R.J.B. (2009). Effect of dietary replacement of sunflower oil with linseed oil on intramuscular fatty acids of lamb meat. Meat Science, 84: 499-505.

Jimenez, J.J., Bernal, J.L., Nozal, M.J., Toribio, L.\& Bernal, J. (2009). Profile and relative concentrations of fatty acids in corn and soybean seed from transgenic and isogenic crops. Journal of Chromatography ,A. 1216: 7288-7295.

Juarez, M., Dugan, M.E.R., Aldai, N., Aalhus, J.L., Patience, J.F., Zijlstra, R.T.\& Beaulieu, A.D.(2010). Increasing omega-3 levels throgh dietary co-extruded flaxseed supplementation negatively affects pork palatability. Food Chemistry, 126:17161723.

Kitessa, S.M. \& Young, P. (2009) Echium oil is better than rapeseed oil in enriching poultry with n-3 PUFA, including eicosapentaenoic acid and docosapentaenoic acid. British Journal of Nutrition, 101: 709-715.

Kaduce, T.L., Chen, Y.,Hell, J.W. \& Spector, A.A.(2008). Docosahexaenoic acid synthesis from n-3 fatty acid precursors in rat hippocampal neurons. Journal Neurochem, 2800.

Karvonen, H.M., Aro, A., Tapola, N.S., Salminen, I., Uusitupa, M.I. \&.Sarkkinen, E.S. ( 2002).Effect of alpha linolenic acid -rich Carmelina sativa oil on serum fatty acid composition and serum lipids in hypercholesterolemic subjects. Metabolism, 51:1253-1260. 
Kouba, M., Enser, M.,Whittington, F.M., Nute, G.R.\& Wood, J.D. (2003). Effect of a highlinolenic diet on lipogenic enzymes activities, fatty acid compostion, and meat quality in the growing pig. Journal Animal Science, 81:1967-1979.

Kouba, M.\& Mourot, J. (2011). A review of nutritional effects on fat composition of animal products with special emphasis on $\mathrm{n}-3$ polyunsaturated fatty acids. Biochimie, 93:13-17.

Leyton, J., Drury, P.J.\& Crawford, M.A., (1987). Differential oxidation of saturated and unsaturated fatty acids in vivo in the rat. British Journal of Nutrition, 57:383-393.

Lichenstein, A.H., Matthan, N. R., Jalbert, S.M.,Resteghini, N.A., Schaefer, E.J. \& Ausman, L.M. (2006). Novel soybean oils with different fatty acid profiles alter cardiovascular disease risk factors in moderately hyperlipidemic subjects. The American Journal of Clinical Nutrition, 84:497-504.

Lorenz, S., Buttner, A., Ender , K., Nuernberg, G., Papstein, H.J., Schieberle, P.\& Nuernberg, K.(2002). Influence of keeping system on fatty acid composition in the longissimus muscle of bulls and odorants formed after pressure-cooking. Eur. Food Res Technol., 214:112-118.

Lozupone, A., Azcona, J.O., Sancho, A. M., Casal, J.J.\& Garcia, P.T. (2009). Efecto del sexo en la composicion de los acidos grasos de los lipidos intramusculares de pollos. XII Congreso Argentino de Ciencia y Tecnologia de Alimentos. Concordia. Entre Rios 7-9 octubre 2009.

Ludden, P.A., Kucuk, O., Rule, D.C.\& Hess,B.W. (2009). Growth and carcass fatty acid composition of beef steers fed soybean oil for increasing duration before slaughter. (2009). Meat Science, 82: 185-192.

Madron, M.S., Peterson, D.G.,Dwyer, D.A., Corl,B.A., Baumgard,L.H., Beermann, D.H.\& Bauman,d.E. (2002). Effect of extruded full-fat soybeans on cojugated linoleic acid content of intramuscular, intermuscular, and subcutaneous fat in beef steers. Journal Animal Science, 80: 1135-1143.

Mandell, I.B., Buchanan-Smith, J.G., Holub, B.J.\& Campbell, C.P. (1998) Effects of fish meal in beef cattle diets on growth performance, carcass characteristics, and fatty acid composition of longissimus Muscle. Journal Animal Science, 75:910-919.

Mir,P.S., McAllister, T.A., Zaman, S., Jones, S.D.M., He, M.L., Aalhus,J.L., Jeremiah, L.E., Goonewardene, L.A.-, Weselake, R..J.\& Mir, Z. (2003).Effect of dietary sunflower oil and vitamin $\mathrm{E}$ on beef cattle performance, carcass characteristics and meat quality. Canadian Journal Animal Science, 83:53-66.

Moghadasian, M.H., (2008). Advances in dietary enrichmente with n-3 fatty acids, Critical Reviews in Food Science and Nutrition, 48:402-410.

Noci, F., French, P., Monahan, F.J.\& Moloney, A.P., (2007). The fatty acid composition of muscle fat and subcutaneous adipose tissue of grazing heifers supplemented with plant oil-enriched concentrates.Journal Animal Science, , 85:1062-1073.

Napier, J.A. ( 2007). The production of unusual fatty acids in transgenic plants. Annu. Rev. Plant. Biol., 58:295-319.

Nguyen, L.Q., Nuijens, M.C.G.A., Everts,H., Salde, N.\& Beynen, A.C. (2003). Mathematical relationships between the intake of n- 6 and n-3 polyunsaturated fatty acids and thir content in adipose tissue of growing pigs. Meat Science, 65:1399-1406. 
Nuernberg, K., Dannenbrger, D., Nuernberg, G., Ender, K., Voigt, J., Scollan, N.D., Wood, J.D., Nute, G.R.\& Richardson, R.I. (2005). Effect of grass-based and a concentrate feeding system on meat quality characteristics and fatty acid composition of longissimus muscle in different cattle breeds. Livesstock Production Science, 94:137147.

Overland,M., Taugbol, O. „Haug, A.\& Sundstol, E. (1996). Effect of fish oil on growth performance, carcass charactristics, sensory parameters, and fatty acid composition in pigs. Acta Agriculturae Scandinavica Section A -Animal Sciene, 46:11-17.

Owen, P.W.\& Singh, A. (2005). Omega 3/6 fatty acids: Alternative source of production. Process Biochemistry, 40:3627-3652.

Pawlosky, R. J., Hibbeln, Lin, Y., Goodson, S., Riggs, P., Sebring, N., Brown, G.L. \& Salem, N. Jr (2003). Effects of beef and fish based diets on the kinetics of n-3 fatty acid metabolism in human subjects. American Journal Clinical Nutrition, 7: 565-572.

Petrie, J.R.,Shrestha, P., Mansour, M.P.\& Nichols, D.N.(2010). Metabolic engineering of omega-3 long-chain polyunsaturated fatty acids in plants using an acyl-CoA $\Delta 6$ desaturase with w3-preference from the marine microalga Micromonas pusilla. Metabolic Engineering ,12:233-240.

Ping,L.,Zhang,L.Y., Yin, J.D., Everts, A.K.R.\& Li, De.F. (2008). Effects of soybean oil and linseed oil on fatty acid composition of muscle lipids and cooked pork flavour. Meat Science, 80: 910-918.

Ponte, P.I.P, Alves, S. P. , Bessa, R.J.B., Ferreira, L.M.A., Gama, L.T., Bras, J.L.A., Fontes, C. M. G. A.\& Prates, J.A.M. (2008). Influence of pasture intake on the fatty acid composition, and cholesterol, tocopherols, and tocotrienols content in meat from free-range broilers. Poultry Science, 87:80-88.

Portolesi, R., Powell, B.C.\& Gibson, R.A. (2007). Competition between 24:5n-3 and ALA for $\Delta 6$ desaturase may limit the accumulation of DHA in HepG2 cell membranes. Journal of Lipid Research, 48: 1592-

Poumes-Ballihaut , C., Langelier, B., Houlier, F., Alessandri, J.M. Durand, G., Latge, C.\& Guesnet, P., (2001). Comparative bioavailability of dietary alpha-linolenic and docosahexanoic acids in the growing rat. Lipids, 36: 793-780.

Preston, R.L. (2004).Typical composition of feeds for cattle and sheep. Beef Mag. http//www.beefmagazine.com/mag/beef_typical_composition_feed/index.html.

Raes, K., De Smet , D. \& Demeyer, D. (2004). Effect of dietary fatty acids on incorporation of long chain polyunsaturated fatty acids and conjugated linoleic acid in lamb,beef and pork meat: A review. Animal Feed Science and Technology, 113:199-221.

Radunz A.E., Wickersham, L.A., Loerch, S.C., Fluharty, F.L., Reynolds, C.K. \& Zerby, H.N. (2009).Effects of dietary polyunsaturated fatty acid composition in muscle and subcutaneous adipose tissue of lamb. Journal Animal Science, 87:4082-4091.,

Riley, P.A., Enser, M., Nute, G.R.\& Wood, J.D. ( 2000). Effects of dietary linseed on nutritional value and other quality aspects of pig muscle an adipose tissue. Animal Science, 71:483-500.

Rymer, C.\& Givens, D.I.,(2005). N-3 fatty acids enrichment of edible tissue of poultry: a review. Lipids, 40:121-130. 
Rizzi, L., Simioli, M., Sardi, L.\& Monetti, P.G. ((2001). Carcass quality, meat chemical and fatty acid composition of lambs fed diets containing extruded soybeans and sunflower seeds.Animal Feed Science and Tecnology, 97:103-114.

Robert,S.S, Singgh,S., Zhou, X.R.,Petrie,J.R.,Blackburn, S., Mansour, P.M.,Nichols, P.D., Liu, Q.\& Green, A.(2005) .Metabolic engineering of Arabidopsis to produce nutritionally important DHA in seed oil. Funct.Plant Biol., 32:473-479.

Rondelli, S.B. , Martinez, O., Casal, J.J.\& Garcia, P.T. (2007). Fatty acid composition of body lipids of broiler fed with different levels of dietary chia seeds. Proceeding $53^{\text {rd }}$ International Congress Meat Science ETecnology, 101-102.

Ruiz-Lopez, N., Haslam, R., Sayanova, O.\& Napier, J. (2010). The production of omega-3 very long-chain polyunsaturated fatty acids in transgenic plants: a sustainable source of omega-3 fish oils.(2010). Chemistry and Physics of Lipids, 1635 Abstract $\mathrm{SO} 27$.

Russo, G.L. (2009). Dietary n-6 and n-3 polyunsaturated fatty acids: From biochemistry to clinical implications in cardiovascular prevention. Biochemical Pharmacology, 77: 937946.

Santos-Silva, J. , Bessa, R. J. B. \& Mendes, I. A. (2003). The effect of supplementation with expanded sunflower seed on carcass and meat quality of lambs raised on pasture. Meat Science, 65:1301-1308.

Sato, S., Xing, A., Ye, X., Schweiger, B., Kinney, A., Graef, G.\& Clement, T. ( 2004). Production of $\lambda$-linolenic acid and stearidonic acid in seeds of marker-free transgenic soybean. Crop Science, 44:646-652.

Sayanova, O.V.\& Napier, J.A. (2004). Eicosapentaenoic acid: biosynthetic routes and the potential for synthesis in trnsgenic plants. Phytochemistry ,65:147-158.

Sirot, V., Oseredzuk, M., Bemrah-Aouachria, N.,Volatier, J.L\& Leblanc, J.C. (2008). Lipid and fatty acid composition of fish and seafood consumed in France: CALIPSO study. Journal of Food Composition and Analysis, 21:8-16.

Ursin, V.M.,(2003).Modification of plant lipids for human health:development of funtional land-based omega-3 fatty acids. Journal of Nutrition, 133: 4271-4274.

Teye, G.A., Sheard, P.R., Whittington, F.M., Nute, G.R., Stewart, A. \& Wood, J.D.(2006). Influence of dietary oil and protein level on pork quality. 1. Effects on muscle fatty acid composition, carcass, meat and eating quality. Meat Science, 73:157-165.

Tikk, K.,Tikk, M.,Aaslyng, M.D., Karlsson, A.H., Lindahl, G.\& Andersen, A.H. (2007). Significancia of fat supplemented diets on pork quality- Connections between specific fatty acids and sensory attributes of pork. Meat Science 77:275-286.

Vasta, V., Priolo, A., Scerra M., Hallet, K.G. , Wood, J.D. \& Doran, O. (2009). $\Delta 9$ desaturase protein expression and fatty acid composition of longissimus dorsi muscle in lamb fed green herbage or concentrate with or without added tannins. Meat Science, 82: 357-364.

Venegas-Caleron, M. Sayanova, O.\& Napier, J.A. (2010). An alternative to fish oils: Metabolic engineering of oil-seed crops to produce omega-3 long chain polyunsaturated fatty acids. Progress in Lipid Research , 49:108-109.

Wachira, A.M., Sinclair, L.A., Wilkinson, R.G., Enser, M., Wood, J.D.\& Fisher, A.V. (2002). Effects of dietary fat source and breed on the carcass composition, n-3 
polyunsaturated fatty acid and conjugated linoleic acid content of sheep and adipose tissue. Journal of Nutrition, 88:697-709.

Wang, H.F., Ye, J.A., Li, C.Y., Liu, J.X.\& Wu, Y.M. (2011). Effects of feeding whole crop rice combined with soybean oil on growth performance, carcass quality characteristics, and fatty acids profile of Longissimus muscle and adipose tissue of pigs. Livestock Science 136: 64-71.

Wiseman, J., Redshaw, M.S.Jagger, S., Nute, G.R.\& Wood, J.D. (2000). Influence of type and dietary rate of inclusion of oil on meat quality of finnishing pigs. Animal Science, 70: 307-315.

Williard, D.E., Harmon, S.D., Kaduce, T.L., Preuss, M., Moore, S.A., Robbins, M.E. et al. (2001). Docosahexaenoic acid synthesis from n-3 PUFA in differentiated rat brain astrocytes. Journal Lipid Research, 42: 1368-1376.

Worm, B.\& Barbier, E.B. (2006). Response to comments on "Impacts of biodiversity loss on ocean ecosystem service. Science, $316: 1285 \mathrm{~d}$

Wood, J.D. \& Enser, M. (1997).factors influencing fatty acid composition in meat and the role of antioxidants in improving meat quality. British Journal of Nutrition, 78:S49-50.

Woods, V.B.\& Fearon, A.M. (2009). Dietary sources of unsaturated fatty acids for animals and their transfer into meat, milk and eggs. A review. Livestock Science , 126:1-20.

Wu, G., Truksa, M., Datla, N., Vrinten, P., Bauer, J., Zank, T.,Cirpus, P., Heinz, E. \& Qiu , X. (2005). Stepwise engineering to produce high yields of very long-chain PUFA in plants. Nat. Biothecnol., 23:1013-1017. 


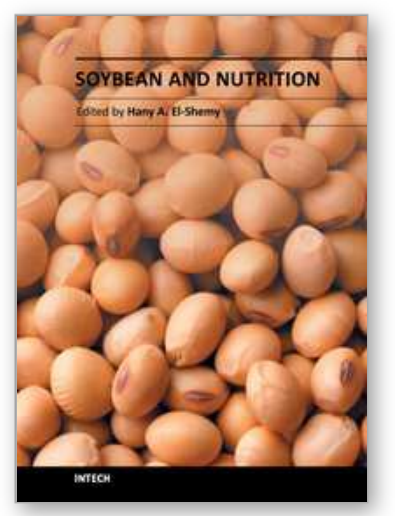

\author{
Soybean and Nutrition \\ Edited by Prof. Hany El-Shemy
}

ISBN 978-953-307-536-5

Hard cover, 476 pages

Publisher InTech

Published online 12, September, 2011

Published in print edition September, 2011

Worldwide, soybean seed proteins represent a major source of amino acids for human and animal nutrition. Soybean seeds are an important and economical source of protein in the diet of many developed and developing countries. Soy is a complete protein and soy-foods are rich in vitamins and minerals. Soybean protein provides all the essential amino acids in the amounts needed for human health. Recent research suggests that soy may also lower risk of prostate, colon and breast cancers as well as osteoporosis and other bone health problems and alleviate hot flashes associated with menopause. This volume is expected to be useful for student, researchers and public who are interested in soybean.

\title{
How to reference
}

In order to correctly reference this scholarly work, feel free to copy and paste the following:

Pilar Teresa Garcia (2011). Metabolism of $\alpha$ - Linolenic Acid (ALA) in Meat Animals, Soybean and Nutrition, Prof. Hany El-Shemy (Ed.), ISBN: 978-953-307-536-5, InTech, Available from:

http://www.intechopen.com/books/soybean-and-nutrition/metabolism-of-linolenic-acid-ala-in-meat-animals

\section{INTECH}

open science / open minds

\section{InTech Europe}

University Campus STeP Ri

Slavka Krautzeka 83/A

51000 Rijeka, Croatia

Phone: +385 (51) 770447

Fax: +385 (51) 686166

www.intechopen.com

\section{InTech China}

Unit 405, Office Block, Hotel Equatorial Shanghai

No.65, Yan An Road (West), Shanghai, 200040, China

中国上海市延安西路65号上海国际贵都大饭店办公楼405单元

Phone: +86-21-62489820

Fax: +86-21-62489821 
(C) 2011 The Author(s). Licensee IntechOpen. This chapter is distributed under the terms of the Creative Commons Attribution-NonCommercialShareAlike-3.0 License, which permits use, distribution and reproduction for non-commercial purposes, provided the original is properly cited and derivative works building on this content are distributed under the same license. 